\title{
Cell death in the host response to infection
}

\author{
K Labbé ${ }^{1}$ and M Saleh ${ }^{\star, 1,2}$
}

Infections elicit diverse responses in the host that include activation of the innate immune system, inflammation and cell death. Pathogen-triggered cell death is manifested by various morphologies indicative of apoptosis, pyroptosis, oncosis or autophagic cell death. The question of whether cell death performs a physiologic function during infection is key to understanding hostpathogen interactions and pathogenesis, and devising targeted therapeutic strategies for infectious diseases. In this review, we examine the different modes of cell death employed by the host during infection, the strategies used by pathogens to manipulate the cell death process and the outcome of cell death, that is, whether it is protective for the host or on the contrary favorable for pathogen dissemination. The pathways leading to cell death by infection are discussed with a focus on the role of pattern recognition receptors in the activation of survival and death effectors.

Cell Death and Differentiation (2008) 15, 1339-1349; doi:10.1038/cdd.2008.91; published online 20 June 2008

The innate immune system possesses many arsenals to fight off pathogens. These include antimicrobial peptides at mucosal surfaces, activation of the complement system in the blood, chemoattraction of immune cells to the infection site and pattern recognition receptors that evolved to sense pathogenassociated molecular patterns and to consequently activate inflammatory pathways required for pathogen elimination. Cell death, which is the most common outcome during infections, is an additional key process that tailors host-pathogen interactions. Various forms of cell death have been described, and the choice of death mode appears to depend on different factors including the nature of the pathogen, pathogen load and site of infection. For instance, infected epithelial cells and lymphocytes undergo apoptosis while macrophages and dendritic cells die primarily by pyroptosis but also, in some cases, by apoptosis. While apoptosis and pyroptosis are quick and occur at relatively low 'physiologic' pathogen burden, oncosis and autophagic cell death take over, respectively, when the cell is overwhelmed with infection or when apoptosis or pyroptosis are inhibited. This does not exclude the concomitant engagement of more than one cell death pathway during infection. In other words, the types of cell death induced by the same pathogen are not mutually exclusive.

\section{Significance of Cell Death During Infection}

Induction of host cell death has been demonstrated in several cases of bacterial, viral and parasitic infections, and has important consequences on pathogenesis. ${ }^{1-3}$ The death of an infected cell is oftentimes concomitant with the death of the infecting agent, and can promote efficient pathogen clearance. Destruction of infected tissues may also eliminate a pathogenic niche, thereby hampering microorganism replication and dissemination. Intracellular pathogens such as Mycobacterium tuberculosis inhibit phagosome-lysosome fusion and thrive by replicating within immature phagosomes. ${ }^{4}$ Stimulation of host macrophage apoptosis eliminates a potential site for future proliferation and destroys the infecting bacteria. ${ }^{5}$ It has been suggested that phagocytosis of apoptotic bodies, sequestering pathogens, permits more efficient fusion of the phagosome with the lysosome resulting in the digestion of the pathogen. ${ }^{6}$ Engulfment of dying macrophages by dendritic cells additionally promotes antigen presentation to $\mathrm{T}$ cells, linking innate and adaptive immunity. ${ }^{7-10}$ Apoptosis of alveolar macrophages in Streptococcus pneumoniae infection also results in pathogen elimination rather than evasion of the immune system. ${ }^{11}$

\footnotetext{
${ }^{1}$ Department of Microbiology and Immunology, McGill University, Montreal, Canada H3A 2B4 and ${ }^{2}$ Department of Medicine, Division of Critical Care, and Centre for the Study of Host Resistance, McGill University, Montreal, Canada H3A 1A1

${ }^{*}$ Corresponding author: M Saleh, McGill University Health Centre, 687 Pine Avenue W, Room M11.41, Montreal, Quebec, Canada H3A 1 A1.

Tel: + 5149341934 extn. 34416; Fax: + 514843 1686; E-mail: maya.saleh@mcgill.ca

Keywords: cell death; infection; innate immunity; host-pathogen interactions; pyroptosis; apoptosis

Abbreviations: NF-kb, nuclear factor-kappa B; MOMP, mitochondrial outer membrane permeabilization; Smac, second mitochondria-derived activator of caspases; DIABLO, direct IAP-binding protein with low pl; BH3, Bcl-2 homology-3; Bcl-2, B-cell lymphoma 2; Bak, Bcl-2 antagonist killer; Bax, Bcl-2-associated protein X; Apaf-1, apoptosis protease-activating factor-1; TRADD, TNF receptor-associated death domain; Bid, BH3-interacting domain death agonist; MAPK, mitogen-activated protein kinase; Bcl-xl, basal cell lymphoma-extra large; c-IAP2, cellular inhibitor of apoptosis; LF, lethal factor; LT, lethal toxin; MKK, mitogen-activated protein kinase kinase; TUNEL, terminal deoxynucleotidyl transferase dUTP nick end labeling; DNA, deoxyribonucleic acid; Mcl-1, myeloid cell leukemia-1; CD95, cluster of differentiation 95; CD95L, CD95 ligand; IL, interleukin; CARD, caspase-activation and recruitment domain; Nod, nucleotide-binding and oligomerization domain; NLR, nod-like receptor; Nalp, NACHT domain-, leucine-rich repeat-, and PYD-containing protein; Naip, neuronal apoptosis inhibitory protein; Ipaf, ice protease-activating factor; ASC, apoptosisassociated speck-like protein containing a CARD; cardinal, CARD inhibitor of NF-kB-activating ligands; COP, CARD-only protein; MOI, multiplicity of infection; ExoU, exoenzyme U; ACG, autophagic cell death; GAS, Group A Streptococcus; MHC, major histocompatibility complex; LPS, lipopolysaccharide; GFP, green fluorescence protein
}

Received 11.4.08; revised 15.5.08; accepted 26.5.08; Edited by PH Krammer; published online 20.6.08 
Pathogens have devised strategies to inhibit cell death for a successful infection. For obligate intracellular organisms such as Rickettsia rickettsii, a viable host cell is required for bacteria to replicate and thrive. By stimulating $N F-\kappa B$ signaling, Rickettsia prevents host cell death and continues to replicate unabated. $^{12}$ Another intracellular pathogen, Chlamidiae spp., also protects infected cells from death during the early invasive stages of the disease, presumably by blocking cytochrome $c$ release from the mitochondria. ${ }^{13}$ These instances clearly indicate that induction of cell death plays a beneficial role in the elimination of infection (Table 1 ).

Conversely, certain pathogens induce death of immune cells as a means to subvert normal host defense mechanisms, and of epithelial and endothelial cells for invasion to deeper layers of an organ and the blood stream. Killing of phagocytes impairs pathogen clearance and is detrimental to the host. By producing cytotoxic pore-forming exotoxins, bacteria such as Bacillus anthracis, ${ }^{14}$ Actinobacillus actinomycetemcomitans ${ }^{15,16}$ and Pseudomonas aeruginosa ${ }^{17,18}$ kill macrophages before they themselves are phagocytosed and destroyed. Similarly, Bordetella pertussis adenylate cyclase hemolysin secretion during the early stages of infection may allow for successful colonization of alveolar tissue by eliminating the local macrophage population. ${ }^{19}$ Cell death of epithelial and endothelial cells contribute to the development of systemic infections, which oftentimes lead to sepsis and septic shock. Host-pathogen interactions in cell death are thus highly complex and involve a delicate balance between pro- and anti death strategies for both the host and pathogen interests.

\section{Apoptosis and Infectious Disease Pathogenesis}

The mechanism of pathogen-induced cell death often involves the modulation of the apoptotic response. Apoptosis is the best-described form of programmed cell death and is mediated by the caspase enzymes, which are cysteinyl aspartate-specific proteases. Twelve caspases have been described in humans, and belong to one of two caspase subfamilies: the cell death or inflammation subfamilies. The apoptotic caspases mediate cell death events, and can be further subgrouped into initiator caspases-2, -8, -9 and -10 and effector/executioner caspases-3, -6 and -7 . Caspases-1, $-4,-5$ and -12 are phylogenetically related and are known as the inflammatory caspases for structural reasons, because only caspase-1 is directly involved in the cleavage and maturation of cytokines. The inflammatory caspases do not participate in classical apoptosis pathways. Synthesized as inactive precursors, procaspases are activated when cleaved by other mature caspases, or by a conformational change and autocatalysis induced through proximity and oligomerization. ${ }^{20}$ Apoptosis occurs when mitochondrial outer membrane permeabilization (MOMP) causes the release of mitochondrial death proteins, including cytochrome $c$ and Smac/DIABLO, into the cytosol. ${ }^{21}$ MOMP is induced under conditions of cellular stress by the intrinsic activation of the Bcl-2 homology3 (BH3)-only proteins, leading to the oligomerization of the pro-apoptotic Bcl-2 family proteins Bak and/or Bax which form the pores through which cytochrome $c$ can enter the cytosol. ${ }^{22}$ Cytochrome $c$ then associates with the cytosolic apoptosis protease activating factor- 1 to recruit and activate caspase- 9 in a protein complex termed the 'apoptosome'. ${ }^{23}$ Active caspase- 9 cleaves and activates the executioner caspases$3,-6$ and -7 that, in turn, process cellular substrates to ultimately kill the cell. Apoptosis can also be induced by the extrinsic stimulation of the tumor necrosis factor receptor family of membrane death receptors. The adapter proteins Fas-associated via death domain and TNFR1-associated death domain protein then recruit and activate caspases- 8 and -10 to form the death-inducing signaling complex. ${ }^{24}$ Active caspase- 8 cleaves and activates caspases- $3,-6$ and -7 directly, and in certain cells, truncates and switches on the BH3-only protein Bid to induce MOMP and caspase-9 activation. Substrate processing by the executioner caspases result in the morphologic features observed in apoptosis ${ }^{25}$ (Figure 1). These include DNA fragmentation and chromatin condensation, nuclear fragmentation, cell shrinkage, loss of membrane asymmetry, the formation of cytoplasmic blebs and of apoptotic bodies and the generation of 'eat-me' signals that stimulate phagocytosis of apoptotic cells by surrounding cells. During apoptosis, dying cells do not release their cytoplasmic content to the extracellular space. Thus, apoptosis does not induce an inflammatory response and is considered to be immunologically silent.

Several pathogens have been reported to trigger apoptosis. This is accomplished through different mechanisms including the production of bacterial toxins or expression of virulence factors that interact directly with key components of the death machinery. ${ }^{1}$ Alternatively, pathogens modulate apoptosis by interfering with the NF- $\mathrm{BB}$ and/or MAPK cell survival pathways, which are activated downstream of pattern recognition receptors, and are responsible for the production of inflammatory mediators as well as survival proteins such as $\mathrm{Bcl}-\mathrm{xl}$ and c-IAP2. For example, Salmonella AvrA and Yersinia YopJ proteins inhibit NF- $\mathrm{KB}$ activation, ${ }^{26-28}$ whereas Bacillus anthracis's protease lethal factor, a component of its lethal toxin (LT), targets MKK6 to dampen MAPK signaling ${ }^{29}$ (Table 1). It is presumed that through inhibition of these pathways, apoptosis is engaged by default.

Caution must be taken when interpreting the effects of a pathogen on cell death induction. Previously, nonapoptotic cell death was considered to be apoptosis based solely on the use of TUNEL-staining that labels DNA fragmentation. However, cells undergoing other forms of cell death also stain positively with TUNEL (pyroptosis section). A better approach to detect apoptosis is therefore the examination of events that are specific to this type of death, such as cytochrome $c$ release from the mitochondria or activation of apoptotic caspases. Genetic studies provide the most stringent evidence of apoptosis induction by a pathogen and allow the evaluation of the effects of cell death on host resistance to infection. An excellent example is that of alveolar macrophage apoptosis by pneumococci. Overexpression of the antiapoptotic protein $\mathrm{Mcl}-1$ in a transgenic mouse model blocks apoptosis and renders mice susceptible to infection, ${ }^{30}$ indicating that apoptosis is indeed triggered by pneumococci and that it is protective for the host. Deletion of CD95 or CD95L, which abrogates the extrinsic cell death pathway, renders mice susceptible to Pseudomonas aeruginosa infection. ${ }^{31}$ Similarly, Helicobacter pylori induces apoptosis of gastric epithelial cells in a Fas-dependent manner, and Fas- 
Table 1 Host cell death during infection

\begin{tabular}{|c|c|c|c|c|c|c|c|}
\hline Pathogen & Disease & Characteristics & $\begin{array}{l}\text { Host cell } \\
\text { death }\end{array}$ & Experimental condition & $\begin{array}{l}\text { Pathogen strategy } \\
\text { Recognition by host }\end{array}$ & $\begin{array}{l}\text { Cell death } \\
\text { outcome }\end{array}$ & Ref \\
\hline Chlamydiae spp. & Chlamydia STD & OI, G-, cocci, non-motile & $\downarrow$ Apoptosis & $\begin{array}{l}\text { Infection of HeLa and U937 cells. Chlamydiae protected } \\
\text { cells from apoptosis by different apoptotic stimuli }\end{array}$ & $\begin{array}{l}\text { Inhibition at the level } \\
\text { of cytochrome } c \\
\text { release }\end{array}$ & $\begin{array}{l}\text { Pathogen } \\
\text { survival }\end{array}$ & 13 \\
\hline R. rickettsii & $\begin{array}{l}\text { Rocky Mountain } \\
\text { spotted fever }\end{array}$ & $\begin{array}{l}\text { OI, G-, } \alpha \text {-proteobacteria, } \\
\text { cocci and bacilli, } \\
\text { non-motile }\end{array}$ & $\downarrow$ Apoptosis & $\begin{array}{l}\text { Infection of endothelial cells. Cells survived unless } \\
\text { NF-kB was inhibited }\end{array}$ & $\uparrow N F-\kappa B$ & $\begin{array}{l}\text { Pathogen } \\
\text { survival }\end{array}$ & 12 \\
\hline B. pertussis & $\begin{array}{l}\text { Pertussis or } \\
\text { whooping cough }\end{array}$ & $\begin{array}{l}\text { FI, G-, } \beta \text {-proteobacteria, } \\
\text { coccobacilli, motile }\end{array}$ & Apoptosis? & $\begin{array}{l}\text { Infection of J774A.1 and alveolar macrophages. DNA } \\
\text { fragmentation and nuclear condensation observed }\end{array}$ & $?$ & $\begin{array}{l}\text { Pathogen } \\
\text { survival }\end{array}$ & 14 \\
\hline B. pseudomallei & Melioidosis & $\begin{array}{l}\text { FI, G-, } \beta \text {-proteobacteria, } \\
\text { bacilli, motile }\end{array}$ & Pyroptosis & $\begin{array}{l}\text { Infection of THP-1 cells. Oncosis phenotype observed } \\
\text { Caspase } 1^{-1-} \text { PEMs are resistant to cytotoxicity at } \\
\text { low MOls }\end{array}$ & $?$ & $?$ & 51 \\
\hline \multirow[t]{2}{*}{ L. pneumophila } & $\begin{array}{l}\text { Legionnaires' } \\
\text { disease }\end{array}$ & $\begin{array}{l}\text { FI, G-, g-proteobacteria, } \\
\text { bacilli, motile }\end{array}$ & Pyroptosis & $\begin{array}{l}\text { Ipaf } \\
\text { infection }^{-1} \text { and caspase- } 1^{-1-} \text { mice are susceptible to }\end{array}$ & $\begin{array}{l}\text { Flagellin recognition } \\
\text { by the IPAF } \\
\text { inflammasome. } \\
\text { Role of Naip5 in } \\
\text { restriction of bacterial } \\
\text { growth. }\end{array}$ & $\begin{array}{l}\text { Pathogen } \\
\text { clearance }^{a}\end{array}$ & 48,49 \\
\hline & & & Autophagy & & & $\begin{array}{l}\text { Pathogen } \\
\text { survival }\end{array}$ & \\
\hline \multirow[t]{3}{*}{$P$. aeruginosa } & $\begin{array}{l}\text { Infection of the } \\
\text { respiratory tract } \\
\text { (Cystic Fibrosis } \\
\text { patients) }\end{array}$ & $\begin{array}{l}\text { FI, G-, } \gamma \text {-proteobacteria, } \\
\text { bacilli, motile }\end{array}$ & Apoptosis & $\begin{array}{l}\text { Mice deficient in CD95 signaling were more } \\
\text { susceptible to P. aeruginosa-induced sepsis. In WT } \\
\text { mice, infection led to lung epithelial cell apoptosis }\end{array}$ & $?$ & $\begin{array}{l}\text { Pathogen } \\
\text { clearance }\end{array}$ & 26 \\
\hline & & & Pyroptosis & $\begin{array}{l}\text { In response to strains not expressing ExoU } \\
\text { Ipaf }^{-l-} \text { mice are susceptible to infection }\end{array}$ & $\begin{array}{l}\text { Recognition by the } \\
\text { Ipaf inflammasome, } \\
\text { not completely } \\
\text { dependent on flagellin }\end{array}$ & $\begin{array}{l}\text { Pathogen } \\
\text { clearance }^{a}\end{array}$ & $46,81,86$ \\
\hline & & & $\begin{array}{l}\text { Caspase-1- } \\
\text { independent } \\
\text { death }\end{array}$ & In response to strains expressing ExoU & $\begin{array}{l}\text { ExoU induces cell } \\
\text { death and caspase-1- } \\
\text { dependent inflammation }\end{array}$ & $\begin{array}{l}\text { Pathogen } \\
\text { survival }\end{array}$ & 46 \\
\hline \multirow[t]{3}{*}{ S. typhimurium } & $\begin{array}{l}\text { Samonellosis } \\
\text { gastroenteritis }\end{array}$ & $\begin{array}{l}\text { FI, G-, } \gamma \text {-proteobacteria, } \\
\text { bacilli, motile }\end{array}$ & Pyroptosis & $\begin{array}{l}\text { Pyroptosis, rather than apoptosis, is the main death } \\
\text { mode since caspase- } 1^{-1-} \text { macrophages are resistant } \\
\text { to cell death. Caspase- } 1^{-1-} \text { mice are susceptible } \\
\text { to infection }{ }^{a}\end{array}$ & $\begin{array}{l}\text { Flagellin recognition } \\
\text { by the IPAF } \\
\text { inflammasome }\end{array}$ & $\begin{array}{l}\text { Pathogen } \\
\text { clearance }^{\text {a }}\end{array}$ & $\begin{array}{l}39-44 \\
76-79\end{array}$ \\
\hline & & & Apoptosis & $\begin{array}{l}\text { Infection of HeLa cells. Apoptosis detected by } \\
\text { Annexin V staining }\end{array}$ & AvrA $\downarrow N F-\kappa B$ & $?$ & \\
\hline & & & Autophagy & & & $\begin{array}{l}\text { Pathogen } \\
\text { clearance }\end{array}$ & 105 \\
\hline \multirow[t]{3}{*}{ S. flexneri } & diarrhea & $\begin{array}{l}\text { FI, G-, } \gamma \text {-proteobacteria, } \\
\text { bacilli, non-motile }\end{array}$ & Pyroptosis & $\begin{array}{l}\text { MOI used was } 10 / \text { cell. caspase }-1^{-1-} \text { macrophages } \\
\text { are more resistant to cell death than WT cells } \\
\text { Caspase- } 1^{-l-} \text { mice are susceptible to infection }\end{array}$ & $\begin{array}{l}\text { Flagellin-independent } \\
\text { recognition by the } \\
\text { Ipaf inflammasome }\end{array}$ & $\begin{array}{l}\text { Pathogen } \\
\text { clearance }^{a}\end{array}$ & \\
\hline & & & $\begin{array}{l}\text { Pyronecrosis } \\
\text { (caspase-1- } \\
\text { independent) }\end{array}$ & $\begin{array}{l}\text { MOI used was } 50 / \text { cell. Death and IL-1 } \beta \text { release were } \\
\text { dependent on Nalp3, Asc but not caspase- } 1\end{array}$ & ? & $?$ & 99 \\
\hline & & & Autophagy & $\begin{array}{l}\text { Observed when caspase- } 1 \text { or Ipaf were deleted } \\
\text { Conversly, inhibition of autophagy enhanced pyroptosis }\end{array}$ & $?$ & $?$ & 85 \\
\hline \multirow[t]{2}{*}{ F. tularensis } & $\begin{array}{l}\text { Tularemia or } \\
\text { rabbit fever }\end{array}$ & $\begin{array}{l}\text { FI, G-, } \gamma \text {-proteobacteria, } \\
\text { coccobacilli, non-motile }\end{array}$ & Pyroptosis & $\begin{array}{l}\text { Caspase }-1^{-1-} \text { and } \mathrm{ASC}^{-1-} \text { macrophages are resistant } \\
\text { to rapid cell death induced by the bacteria. Caspase-1 } 1^{-1-} \\
\text { and } \mathrm{ASC}^{-1-} \text { mice are susceptible to infection }\end{array}$ & NLR unknown & $\begin{array}{l}\text { Pathogen } \\
\text { clearance }^{a}\end{array}$ & 47,76 \\
\hline & & & Autophagy & & & $\begin{array}{l}\text { Pathogen } \\
\text { clearance }\end{array}$ & 106 \\
\hline
\end{tabular}


Table 1 (Continued)

\begin{tabular}{|c|c|c|c|c|c|c|c|}
\hline Pathogen & Disease & Characteristics & $\begin{array}{l}\text { Host cell } \\
\text { death }\end{array}$ & Experimental condition & $\begin{array}{l}\text { Pathogen strategy } \\
\text { Recognition by host }\end{array}$ & $\begin{array}{l}\text { Cell death } \\
\text { outcome }\end{array}$ & Ref \\
\hline \multirow[t]{2}{*}{$\begin{array}{l}\text { Y. pestis Y. } \\
\text { pseudotuberculosis }\end{array}$} & \multirow[t]{2}{*}{ Bubonic plague } & \multirow[t]{2}{*}{$\begin{array}{l}\mathrm{FI}, \mathrm{G}-, \gamma \text {-proteobacteria, } \\
\text { bacilli, motility is } \\
\text { temperature-dependent }\end{array}$} & Apoptosis & $\begin{array}{l}\text { Infection of macrophages inhibit NF-kB and MAPK } \\
\text { signaling in a YopJ-dependent manner }\end{array}$ & $\begin{array}{l}\text { YopJ NF-kB and MAPK } \\
\text { signaling }\end{array}$ & $\begin{array}{l}\text { Pathogen } \\
\text { survival }\end{array}$ & 22,23 \\
\hline & & & Pyroptosis & $\begin{array}{l}\text { TLR stimulation switches the death mode from } \\
\text { apoptosis to pyroptosis }\end{array}$ & YopJ-independent & $\begin{array}{l}\text { Pathogen } \\
\text { clearance }\end{array}$ & 50 \\
\hline H. pylori & $\begin{array}{l}\text { Gastric ulcers, } \\
\text { gastric cancer }\end{array}$ & $\begin{array}{l}\text { E, G-, } \varepsilon \text {-proteobacteria, } \\
\text { helical, motile }\end{array}$ & $\begin{array}{l}\text { Gastric EC } \\
\text { apoptosis }\end{array}$ & $\begin{array}{l}\text { Infection of Fas-deficient mice resulted in a more } \\
\text { severe disease. In WT mice, infection led to gastric } \\
\text { epithelial cell apoptosis }\end{array}$ & $?$ & $\begin{array}{l}\text { Milder } \\
\text { disease }\end{array}$ & 27 \\
\hline S. pneumoniae & $\begin{array}{l}\text { Pneumonia, otitis } \\
\text { media, meningitits }\end{array}$ & $\begin{array}{l}\mathrm{E}, \mathrm{G}+\text {, capsulated, cocci, } \\
\text { non-motile }\end{array}$ & Apoptosis & $\begin{array}{l}\text { Macrophages expressing Mcl-1 as a transgene } \\
\text { exhibit a delay in apoptosis and bacterial killing }\end{array}$ & $\begin{array}{l}\text { Induction of a BH3-only } \\
\text { Mcl-1 splice variant }\end{array}$ & $\begin{array}{l}\text { Pathogen } \\
\text { clearance }\end{array}$ & 25 \\
\hline L. monocytogenes & $\begin{array}{l}\text { Listeriosis } \\
\text { gastroenteritis }\end{array}$ & $\begin{array}{l}\mathrm{FI}, \mathrm{G}+\text {, bacilli, motile at } \\
\text { lower temperatures }\end{array}$ & $\begin{array}{l}\text { Pyroptosis } \\
\text { Autophagy }\end{array}$ & $\begin{array}{l}\text { Bacterial killing was delayed in caspase-1-deficient } \\
\text { mice. Caspase- } 1^{-1-} \text { mice are susceptible to infection }\end{array}$ & $\begin{array}{l}\text { Listeria is detected by } \\
\text { the Nalp3 inflammasome }\end{array}$ & $\begin{array}{l}\text { Pathogen } \\
\text { clearance } \\
\text { Pathogen } \\
\text { clearance }\end{array}$ & $\begin{array}{l}45,76 \\
104\end{array}$ \\
\hline B. anthracis & Anthrax & $\begin{array}{l}\mathrm{FI}, \mathrm{G}+\text {, capsulated, } \\
\text { bacilli, form endospores }\end{array}$ & $\begin{array}{l}\text { Apoptosis } \\
\text { Pyroptosis }\end{array}$ & $\begin{array}{l}\text { Treatment of LPS-activated BMDM or J774A.1 } \\
\text { with LF induces apoptosis }\end{array}$ & $\begin{array}{l}\text { LF processes MKK6 } \\
\text { and p38 signaling } \\
\text { LT recognition by the } \\
\text { Nalp1b inflammasome }\end{array}$ & $?$ & $\begin{array}{l}24 \\
80\end{array}$ \\
\hline $\begin{array}{l}\text { Group A } \\
\text { streptococcus } \\
\text { (Streptococcus } \\
\text { pyogenes or GAS) }\end{array}$ & $\begin{array}{l}\text { Scarlet fever and } \\
\text { pueperal sepsis } \\
\text { (childbirth fever) }\end{array}$ & $\begin{array}{l}\mathrm{E}, \mathrm{G}+\text {, capsulated, cocci, } \\
\text { non-motile }\end{array}$ & Autophagy & Atg $5^{-1-}$ cells allowed GAS survival & & $\begin{array}{l}\text { Pathogen } \\
\text { clearance }\end{array}$ & 103 \\
\hline \multirow[t]{3}{*}{ M. tuberculosis } & \multirow[t]{3}{*}{ Tubreculosis } & \multirow[t]{3}{*}{$\begin{array}{l}\mathrm{FI} \text {, phylogenetically } \\
\mathrm{G}+\text { but stains acid fast, } \\
\text { bacilli, non-motile }\end{array}$} & Apoptosis & BCG (Bacillus Calmette Guerin) & $\begin{array}{l}\text { Recognized by TLR2 } \\
\text { and Nod2 }\end{array}$ & $\begin{array}{l}\text { Pathogen } \\
\text { clearance }\end{array}$ & 5,6 \\
\hline & & & Autophagy & BCG and MTB & & $\begin{array}{l}\text { Pathogen } \\
\text { clearance }\end{array}$ & 102 \\
\hline & & & Oncosis & MTB (virulent M. tuberculosis) & & $\begin{array}{l}\text { Pathogen } \\
\text { survival }\end{array}$ & 97,98 \\
\hline T. gondii & Taxoplasmosis & $\begin{array}{l}\text { Ol parasite, crescent } \\
\text { shape, polarized, motile }\end{array}$ & Autophagy & & & $\begin{array}{l}\text { Pathogen } \\
\text { clearance }\end{array}$ & 103 \\
\hline Poliovirus & Poliomyelitis & $\begin{array}{l}\text { Picornaviridae family } \\
\text { single-stranded positive- } \\
\text { sense RNA genome }\end{array}$ & Autophagy & & & $\begin{array}{l}\text { Pathogen } \\
\text { survival }\end{array}$ & 107,10 \\
\hline Rhinovirus & Common cold & $\begin{array}{l}\text { Picornaviridae family } \\
\text { single-stranded positive- } \\
\text { sense RNA genome }\end{array}$ & Autophagy & & & $\begin{array}{l}\text { Pathogen } \\
\text { survival }\end{array}$ & 107,10 \\
\hline
\end{tabular}

OI, obligate intracellular; G-/+, gram negative/positive; FI, facultative intracellular; PEM, peritoneal exudates macrophage; EC, epithelial cell; BMDM, bone marrow-derived macrophage; BCG, Bacillus Calmette-Guerin; MTB, mycobacterium tuberculosis; TLR, toll-like receptor; RNA, ribonucleic acid; LPS, lipopolysaccharide. ${ }^{2}$ However it is difficult to conclude that cell death in this case is required for pathogen clearance since caspase-1 is also needed for cytokine production. In certain infections, administration of recombinant IL-18 reversed the phenotype, enhanced pathogen clearance and rendered caspase-1-deficient mice more resistant to the
infection. The question is then whether pyroptosis is required for cytokine release? 


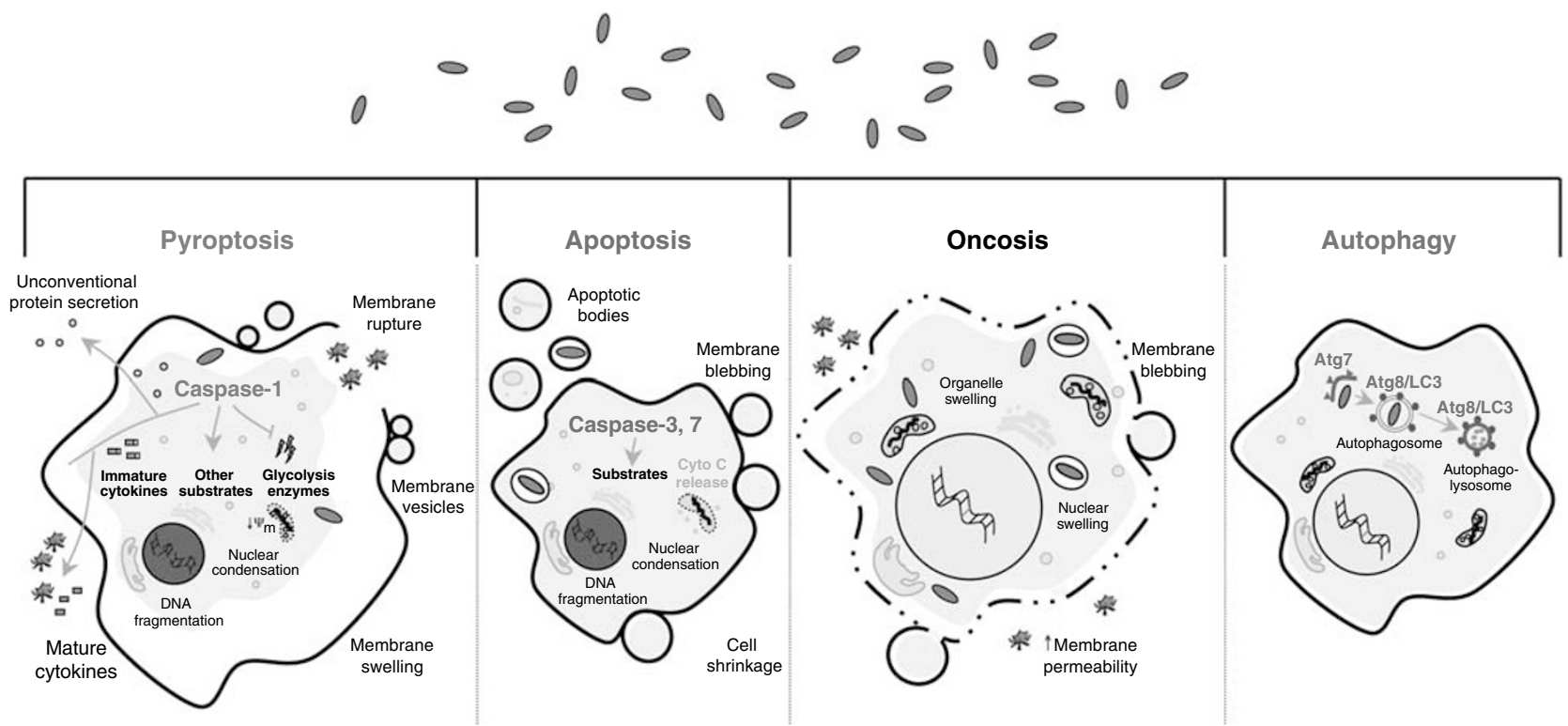

Figure 1 Pathogen-induced host cell death. Several forms of host cell death have been described during infection. The type of death the cell undergoes depends on the nature of the pathogen, pathogen load and site of infection. Pyroptotic, apoptotic, autophagic or oncotic cells display a distinct set of morphological and biochemical characteristics, some of which are shared. Whereas apoptosis and autophagy do not induce inflammation, cytokine release and escape of cytoplasmic content during pyroptosis or oncosis are highly inflammatory events. Pathogens are depicted as red ovals. During pyroptosis, pathogens (or pathogenic products) in the cytosol are detected by caspase-1-activating inflammasomes. During apoptosis, pathogens are contained within apoptotic bodies and digested in the lysosomes of phagocytes that engulf apoptotic cells. During autophagy, pathogens are surrounded by autophagosomes and delivered to the lysosomes through autophagosome-lysosome fusion. Although apoptosis, pyroptosis and autophagy are generally beneficial to the host, oncosis favors pathogen dissemination

deficient mice have an enhanced disease severity as compared with wild-type mice. ${ }^{32}$ Overcoming Fas-mediated apoptosis in this case accelerates $H$. pylori-induced gastric cancer, highlighting the key role of apoptosis not only in the host defense to infection but also in protection from gastric cancer. $^{33}$ Indeed, apoptosis has multifaceted roles in hostpathogen interactions. In addition to containing pathogen dissemination, apoptosis is required for termination of the inflammatory response, as it eliminates inflammatory cells following the control of infection. ${ }^{34,35}$ The secretion of cytotoxic compounds by activated neutrophils lead to significant bystander cell damage, and the neutrophil must be eliminated following pathogen killing. In cases of delayed apoptosis or pathogen-induced cell lysis, disease pathogenesis is amplified with significant tissue damage. On the other hand, apoptosis could be pathogenic. During sepsis, lymphocytes are depleted by apoptosis, which leads to anergy and immunosuppression. ${ }^{36}$ In an experimental model of sepsis, inhibition of apoptosis by selective caspase- 3 inhibitors ${ }^{37}$ or by $\mathrm{Bcl}-2$ overexpression ${ }^{38}$ was shown to lower sepsis-related mortality.

\section{Pyroptosis: a Caspase-1-Dependent Cell Death}

Shigella flexneri, the etiological agent of bacillary dysentery, is an invasive bacteria that penetrates the colonic tissue to initiate acute inflammation. ${ }^{39} \mathrm{~A}$ facultative intracellular pathogen, Shigella invades eukaryotic cells and evades the phagosome to enter the cytosol. ${ }^{40}$ Shigella was the first invasive bacterial pathogen reported to induce programmed cell death in host macrophages. ${ }^{41}$ Initial reports described
Shigella-induced macrophage death as apoptosis, but further investigation uncovered a cell death pathway mediated not by the apoptotic effector caspase-3, but by the inflammatory caspase-1. ${ }^{42,43}$ This dependence on caspase- 1 activation was demonstrated both pharmacologically, using the caspase-1-specific inhibitor Ac-YVAD-CHO, and genetically, in macrophages derived from caspase-1-deficient mice. ${ }^{42,43}$ In both cases, macrophages lacking caspase-1 activity were resistant to Shigella-induced death, while caspase- $3^{-/}$ macrophages were not. Shigella also stimulated macrophage death independently of the tumor suppressor p53, which is necessary for apoptosis downstream of a number of stimuli, and regardless of the apoptosis inhibitor $\mathrm{Bcl}-2 .^{43}$ Together, these findings establish that Shigella infection kills macrophages in a caspase-1-dependent manner distinct from apoptosis.

As with the Shigella bacteria, caspase-1-dependent cell death has been extensively reported in Salmonella typhimuriuminfected macrophages. ${ }^{44-47}$ Macrophages exposed to this facultative intracellular bacteria are killed within minutes of infection, whereas cells treated with $\mathrm{YVAD}^{45}$ or genetically deficient in caspase- $1,{ }^{46}$ are resistant to this rapid cell death. Also, Salmonella-induced caspase-1 dependent cell death does not lead to activation of caspases-3, -6 or $-7,{ }^{45,48}$ again indicating a form of death independent of apoptotic pathways. Interestingly, caspase-1 dependent cell death during Salmonella infection has also been described in dendritic cells, ${ }^{49}$ suggesting that this form of cytotoxicity is not restricted to macrophages, but may occur in several immune cell types. Since these initial reports, caspase-1-dependent cell death has been described in macrophages infected with Listeria 
monocytogenes, ${ }^{50}$ Pseudomonas aeruginosa, ${ }^{51}$ Francisella tularensis, ${ }^{52}$ Legionella pneumophila, ${ }^{53,54}$ Yersinia pseudotuberculosis ${ }^{55}$ and Berkholderia pseudomalle ${ }^{56}$ (Table 1).

Caspase-1 (also known as interleukin (IL)-1 $\beta$ converting enzyme, or ICE) was the first mammalian caspase to be described $^{57}$ and is the prototypical member of the inflammatory caspase subfamily. Like all caspases, caspase-1 is synthesized as an inactive zymogen that requires activation for catalysis. Active caspase- 1 is responsible for the cleavage of pro-IL-1 $\beta$, pro-IL-18 and pro-IL-33 into their secreted, biologically active cytokine forms ${ }^{58,59}$ and does not play a role in the classical apoptotic pathways. Indeed, caspase-1deficient cells are fully susceptible to pro-apoptotic stimuli such as staurosporine ${ }^{60,61}$ Pathogens causing cell death via caspase- 1 activation also induce the production of IL-1 $\beta$ and IL-18. These cytokines play a central role in the inflammatory response to infection by recruiting immune cells and inducing further production of cytokines. ${ }^{62}$ Their cleavage and release, however, are not required for cytotoxicity. ${ }^{63}$ Nonetheless, the production of IL-1 $\beta$ and IL-18 during caspase-1-dependent cell death results in a highly inflammatory state, much unlike the immunologically silent apoptotic death. The inflammatory nature of caspase-1-dependent cell death has lead to the recent coining of the term 'pyroptosis', 44 as 'pyro' or fire, denotes the release of proinflammatory mediators, and 'ptosis' denotes falling, a term commonly used to describe cell death.

\section{Morphology of Pyroptotic Cells}

The morphology of caspase-1-dependent cell death or pyroptosis is still poorly defined; however, published descriptions of pyroptotic cells indicate a distinct combination of physical characteristics shared by both apoptotic and necrotic cells (Figure 1). Pyroptotic cells loose their mitochondrial membrane potential and undergo DNA fragmentation and nuclear condensation (Figure 2) and, like apoptotic cells, show positive TUNEL staining. ${ }^{52,55,63,65,66}$ The TUNEL positivity of Salmonella and Shigella infected macrophages initially lead to the assumption that the cell death induced by these bacteria was apoptotic. ${ }^{66,67}$ The most notable morphological feature of pyroptosis is the loss of plasma membrane integrity and release of cytoplasmic content and membrane vesicles into the extracellular milieu. ${ }^{45,48,68}$ The plasma membrane ruptures then appears to reseal rapidly and starts to swell (Figure 2). This is a shared characteristic with oncotic cells but not apoptotic cells, in which the plasma membrane remains intact until the dying cell is eventually phagocytosed by resident macrophages. Although complete disruption of the pyroptotic cell plasma membrane has been observed microscopically, ${ }^{48,68}$ the mechanisms by which cell lysis occurs is still unknown. It has been suggested that small-ion permeable pores form on the surface of pyroptotic cells which lead to loss of cellular ionic gradients. ${ }^{69}$ The resulting osmotic pressure would result in water influx, followed by cell swelling and lysis. Yet it should be noted that the evidence supporting this proposition is based on molecule exclusion studies and flow cytometry analysis performed on a late-stage infected macrophage-like cell line, while caspase-1-dependent cell death in primary macrophages occurs rapidly following infection. We have recently reported the caspase-1 digestome and have shown that caspase-1 targets multiple essential proteins in the cell that function in the maintenance of the cytoskeleton and in bioenergetic pathways. Therefore, we propose that processing of substrates by caspase- 1 is responsible for the phenotype of pyroptotic cells. ${ }^{70}$ Caspase- 1 also appears to be required for unconventional protein secretion. ${ }^{71}$ The release of cytoplasmic contents is a highly inflammatory event, which underscores the distinct form and function of this programmed cell death.
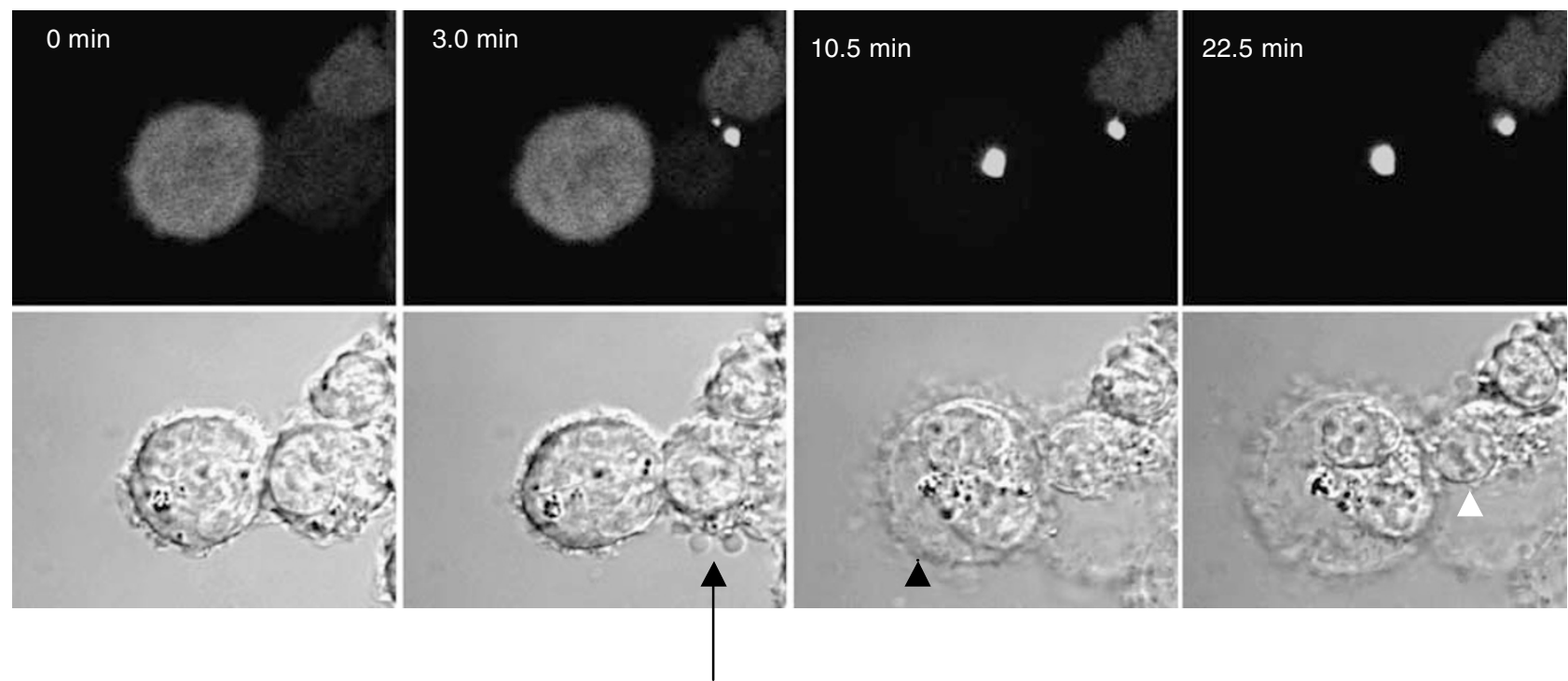

Figure 2 Imaging of pyroptosis by time-lapse confocal microscopy. Pyroptosis was induced in differentiated THP-1-ASC-GFP cells with crude LPS. Top row, fluorescence images depicting the formation of the ASC-GFP speck (pyroptosome). Plasma membrane rupture and membrane vesicles were observed rapidly (black arrow), followed by membrane re-sealing and swelling (black arrowhead) and nuclear condensation (white arrowhead). (These images are courtesy of Dr. E Alnemri) 


\section{Activators of Pyroptosis: the Inflammasomes and Pyroptosome}

Caspase- 1 is synthesized as an inactive $44 \mathrm{kDa}$ precursor protein consisting of an $\sim 10 \mathrm{kDa}$ CARD domain (caspaseactivation and recruitment domain), a large subunit (p20) and a small subunit ( $p 10)$. Upon activation, caspase-1 undergoes auto-processing. This releases the CARD domain and results in the formation of a tetramer of two large and two small subunits that constitute the active enzyme. Caspase-1 oligomerization and subsequent auto-processing is triggered by the formation of a cytosolic multiprotein, activating platform termed the 'inflammasome'. The inflammasome is scaffolded by members of the cytosolic Nod-like receptors (NLRs) family, which recruit caspase-1 through adapter molecules. ${ }^{72} \mathrm{NLRs}$ are thought to act as intracellular pattern-recognition receptors, and their activation by their respective agonists leads to signaling cascades that engage the innate immune response. ${ }^{73}$ To date, four inflammasomes have been characterized, each assembled around a different NLR, namely Nalp-1, Nalp-3, Naip5 or Ipaf. ${ }^{74}$ When activated, Nalp-3 associates with the adapter proteins ASC and Cardinal. ${ }^{75,76}$ Nalp1, Ipaf and Naip5 appear to require only ASC for full functionality. ${ }^{47,77-79}$ While Nalp1 binds ASC, direct interaction between ASC and either Naip5 or Ipaf has not yet been demonstrated. Through CARD-mediated binding, multiple copies of caspase-1 are recruited to the inflammasome and activated therein by proximity. Inflammasome assembly and caspase-1 activation occur in response to several pathogenic stimuli. The inflammasome components required for caspase-1 activation by several bacteria have been elucidated genetically through the investigation of knock-out animals (reviewed in, Mariathasan S and Monack DM). ${ }^{80}$ It is with the use of ASC, Ipaf and Nalp3-deficient primary macrophages that Salmonella typhimurium was found to require Ipaf and ASC to activate caspase-1, ${ }^{47,81-84}$ whereas Staphylococcus aureus and Listeria monocytogenes required Nalp3 and ASC, but not Ipaf. ${ }^{81}$ Curiously, Francisella tularensis required only ASC, independently of Ipaf or Nalp3, to activate caspase$1^{52,81}$ This suggests the possible existence of an unidentified NLR inflammasome sensor that would associate with ASC during Francisella infection. Recently, genetic studies have shown that anthrax LT derived from Bacillus anthracis activates caspase-1 via Nalp1b, ${ }^{85}$ and is to date the only known agonist of this inflammasome. Macrophages derived from 129Sv or BALBc mice express a functional Nalp1b protein, and are susceptible to LT-mediated pyroptosis, whereas the C57BL6 strain Nalp1b gene is mutated and nonfunctional, conferring LT-resistance to macrophages derived from these mice. The role the Nalp1b inflammasome plays during infection with live Bacillus anthracis is not yet known, nor is its implication during other types of bacterial infections.

Interestingly, inflammasome requirements seem to differ between caspase-1-dependent cytokine secretion and pyroptosis. Both Ipaf and ASC are fully required for IL-1 $\beta$ production by Salmonella-infected macrophages, yet only Ipaf-deficient macrophages are fully resistant to Salmonellainduced pyroptosis, whereas ASC-deficient cells are only partially protected. ${ }^{47}$ Similarly, recently published data show that Pseudomonas aeruginosa requires both Ipaf and ASC to induce IL-1 $\beta$ secretion, but that ASC is dispensable for inducing pyroptosis. ${ }^{51,86}$ Conversely, ASC has been shown to induce pyroptosis in the human monocytic THP-1 cell line, engineered to express a GFP-tagged ASC. Upon stimulation with inflammatory agonists, ASC was shown to oligomerize into a single cytoplasmic 'pyroptosome' required for caspase1 activation and induction of pyroptosis. The ASC oligomer was also shown to form in primary macrophages of both wildtype and caspase-1-deficient mice, though pyroptosis was not induced in the absence of caspase-1. ${ }^{68}$ These results indicate that Ipaf and ASC play different roles in promoting caspase-1 function and that caspase- 1 activation is more complex than the currently held model.

\section{Modulation of Caspase-1 Activity}

During infection, delivery of bacterial effector molecules to the host cell cytoplasm is critical for caspase- 1 activation. Several bacterial strains possess delivery systems responsible for the translocation of effector molecules into the host cytosol, which permit bacterial internalization and/or replication. ${ }^{87,88}$ Disruption of the type four secretion system in Legionella pneumophila, ${ }^{53,54,89}$ of the Listeria monocytogenes listeriolysin $\mathrm{O}$, or of the type three secretion system in Salmonella typhimurium, ${ }^{47,82,83}$ Shigella flexneri, ${ }^{90}$ Yersinia pseudotuberculosis $^{55}$ and Pseudomonas aeruginosa ${ }^{51}$ inhibits caspase- 1 activation by these pathogens. Although initial reports had proposed that proteins of the type three secretion system, SipB in Salmonella ${ }^{44}$ and IpaB in Shigella, ${ }^{43}$ could directly bind and activate caspase-1, recent studies indicate a more indirect role for such bacterial delivery systems, presumably by allowing the inflammasome agonist to reach the cytosol. ${ }^{82,83}$ In contrast, the inhibitor of actin rearrangement, cytochalasin $D$, interferes with bacterial entry into the cytosol and caspase-1 activation. ${ }^{41,49,52,56,66}$

In some cases, the effector molecule responsible for caspase-1 activation has been identified. For the flagellated bacteria Salmonella typhimurium, ${ }^{82,83}$ Legionella pneumophila, ${ }^{54}$ and Pseudomonas aeruginosa, ${ }^{86,91}$ proper expression of flagellin is required for caspase- 1 activation. In addition, purified flagellin is also able to induce caspase- 1 activity if introduced into the cytosol through cationic lipids such as DOTAP. ${ }^{82,83,86}$ Although stimulating IL-1 $\beta$ and IL-18 secretion, cytosolic flagellin alone is not sufficient to induce cell death. Indeed, activation of caspase- 1 in the absence of cell death is seen in virtually all cases of inflammasome activation with purified agonists. ${ }^{92}$ It seems, therefore, that bacterial infection is inducing additional factors that lead to cell death. One possibility is that the 'choice' between proinflammatory cytokine production and death occurs at a threshold of caspase- 1 activation. At low levels, caspase- 1 antagonists may be able to counteract its cytotoxic activities, whereas the caspase-1 production induced during a bacterial infection overcomes these inhibitory effects and results in pyroptosis.

Host cells are capable of expressing molecules able to antagonize the inflammasome and hamper caspase-1 activity. COP (CARD-Only Protein) and Iceberg are two human proteins containing CARD domains closely resembling that of procaspase-1. They are thought to act as 
dominant negative inhibitors of caspase-1 by interfering with CARD domain interactions, and thus limiting caspase-1 activation in human cells. ${ }^{93}$ The negative regulator Pyrin might function in a similar manner by disrupting association with the pyrin domain of ASC, thus inhibiting caspase-1 activation. ${ }^{94,95}$ Recently, we have described that mouse caspase-12 acts as an antagonist of caspase- 1 activity. ${ }^{96}$ Constitutive levels of caspase-12 are low in macrophages, but protein expression is highly inducible upon bacterial infection. ${ }^{96}$ Little is known about how these endogenous inhibitors are engaged by the inflammasome and the role they play in regulating pyroptosis has yet to be determined.

\section{Physiological Significance of Pyroptosis}

By inducing cell death during infection, the host is effectively eliminating a pathogenic niche and limiting bacterial replication. Alternatively, by inducing cell death, the bacteria is eliminating host immune cells, and thus weakening the immune response. What is interesting with pyroptosis, is that the death of a cell is necessarily associated with a proinflammatory response. By secreting the pyrogenic factors IL-1 $\beta$ and IL-18 and releasing cytoplasmic content into the extracellular milieu, pyroptotic cells are promoting the host inflammatory response and the recruitment of additional effector cells to the site of infection.

Determining the role of caspase-1-dependent cell death during in vivo infection is difficult, as the activities of caspase-1 in response to microbial pathogens extend beyond pyroptosis. Interpreting data from caspase-1-deficient animals must take these multiple functions into consideration. Indeed, caspase-1 induces IL-1 $\beta$ secretion, the cytokine considered to be the most potent endogenous pyrogen. IL- $1 \beta$ is capable of causing inflammatory cell infiltration and increased production of additional proinflammatory mediators with important physiological consequences such as fever, hypotension, and metabolic derangements. ${ }^{97}$ Caspase-1 knockout animals are resistant to endotoxemia and septic shock. ${ }^{61}$ Unexpectedly, this resistance is not due to reduced IL-1 $\beta$ or IL-18 production, as IL-1 $\beta$-deficient mice are fully sensitive to endotoxic shock, ${ }^{98}$ as are IL-1 $\beta$ and IL-18 double knockout animals. ${ }^{99}$ The elucidation of the caspase-1 digestome identified additional substrates of caspase-1 that are thought to contribute to its effects during the host response to infections and in septic shock. ${ }^{70}$ An additional layer of complexity can be attributed to redundancy in pathogeninduced host cell death. Although caspase-1 deficiency renders macrophages resistant to rapid pyroptotic cell death, these cells will nonetheless perish following infection due to the engagement of alternate death pathways.

\section{Caspase-Independent Cell Death: Oncosis and Pyronecrosis}

Until recently, cell death had been divided into two types: apoptosis, or programmed cell death, which utilizes the cell's own signaling pathways to induce death, and oncosis/ necrosis, which is highly inflammatory and occurs due to extracellular stresses such as mechanical disruption or abrupt changes in culture conditions or temperature. Necrosis is described by pathologists as a postmortem state of dead cells that have come into equilibrium with their environment but does not explain the cause of death. ${ }^{100}$ Oncosis, on the other hand, describes a caspase-independent cell death characterized by swelling, increased permeability and membrane rupture that is often referred to as necrosis (Figure 1). This form of cell death was believed to be accidental and uncontrolled. However, recent findings suggest a programmed basis to oncosis/necrosis. ${ }^{101}$ Owing to better technologies, imaging techniques and knowledge of signaling pathways, our current understanding of cell death depicts a much more complex situation. Cells possess several mechanisms to execute cell death. Several of these are caspaseindependent, and have been described for infected cells. For instance, although caspase-1-deficient macrophages are initially resistant to death by many bacteria, they eventually succumb in a caspase-independent fashion. Similarly, in the case of $M$. tuberculosis, infected macrophages undergo apoptosis, but inhibition of caspases does not prevent cell death. A serine protease inhibitor appears to block this caspase-independent death. ${ }^{102}$ Moreover, at high multiplicity of infection (MOI), $M$. tuberculosis induces a caspaseindependent cell death that is not observed at low MOI. ${ }^{103}$ In the case of Shigella, the primary death mode is pyroptosis, induced through the Ipaf-caspase- 1 inflammasome. ${ }^{90}$ However, at higher MOI, Shigella induces a caspase-1-independent form of cell death termed pyronecrosis. ${ }^{104}$ Diseaseassociated cryopyrin appears to trigger this death mode as well, which is independent of caspase- 1 but presumably requires cathepsin B. ${ }^{104}$ The IPAF-caspase-1 inflammasome has been recently shown to be essential for the initiation of a proper innate immune response to Pseudomonas aeruginosa. ${ }^{51,91}$ Virulent $P$. aeruginosa isolates that evade the immune response express the effector protein exoenzyme $U$ (ExoU). Interestingly, ExoU blocks caspase-1 activity and prevents the production of proinflammatory cytokines. However, despite inhibiting caspase-1, ExoU-expressing $P$. aeruginosa very efficiently killed macrophages. ${ }^{51}$ Therefore, it appears that caspase-independent death occurs as a 'back-up' strategy or when cells are overwhelmed with a high bacterial load. Whether it performs a physiologic function similar to that of apoptosis or pyroptosis remains open for debate.

\section{Autophagy and Autophagic Cell Death}

Autophagy is a tightly regulated programmed process, orchestrated by the ATG/Beclin proteins, and characterized by lysosomal enzyme degradation of intracellular components captured within a double membrane vacuole termed the autophagosome $^{105}$ (Figure 1). Autophagy is essential for the removal of damaged organelles and long-lived cytosolic macromolecules to maintain energy homeostasis, and hence cell survival, during starvation conditions. When excessive, however, autophagy results in autophagic cell death (ACD). Morphological features of ACD include vacuolization, degradation of cytoplasmic content and lack of chromatin condensation. Cells undergoing ACD may be internalized by neighboring cells. ACD is therefore a noninflammatory form of cell death, as intracellular content is not spilled to the extracellular space. 
Autophagy can be triggered in infected host cells, presumably as a host defense mechanism for eliminating the pathogen without disposing of the entire cell. ${ }^{106}$ In a situation where normal phagolysosomal maturation is blocked, such as during Mycobacterium tuberculosis infection, the initiation of autophagy can overcome this inhibition and result in bacterial degradation. ${ }^{107}$ Listeria monocytogenes, Salmonella enterica, Francisella tularensis and the parasite Toxiplasma gondii, have also been shown to be targeted by autophagy. ${ }^{107-111}$ To demonstrate the importance of autophagy in intracellular pathogen clearance, Nakagawa and colleagues have shown the effective elimination of the pathogenic group $A$ Streptococcus (GAS) within non-phagocytic cells through autophagy. ${ }^{108}$ Atg $^{-1}$ cells allowed GAS survival, replication and subsequent release to the surroundings, indicating that autophagy is protective for the host.

Conversely, autophagosome formation may support the replication of poliovirus, rhinovirus and Legionella pneumophila in host cells, as these microorganisms have devised ways to subvert the autophagosome machinery to their own benefits. $^{112,113}$

Autophagy has recently been shown to be involved in antigen processing of endogenously synthesized cytosolic proteins for major histocompatibility complex (MHC) class II presentation, linking innate and adaptive immunity. ${ }^{114}$ This process has been suggested to complement MHC class I presentation as proteins unable to be degraded by the proteasome, such as aggregate-prone proteins, may be digested by autophagy and presented on MHC class II. Therefore, triggering of autophagy in infected cells may lead to enhanced stimulation of $\mathrm{CD}^{+}{ }^{+} \mathrm{T}$ cells specific for the pathogen and may be exploited for potential new therapeutics.

\section{Conclusion}

The type and outcome of pathogen-induced cell death depend on the nature of the infection itself. A wide variety of microorganisms have evolved mechanisms to modulate host cell death and to use a step in cell death to their advantage. Characterization of pathogen-induced cell death not only gives insight into disease pathogenesis, but also helps in the understanding of the basic mechanisms of the different cell death modalities under normal physiological conditions. Greater knowledge of how cell death modulates the host response to pathogens will provide potential targets for new therapeutics.

Acknowledgements. We apologize to the authors who made important contributions to the field, but have not been cited due to space limitations. We thank Dr. Emad Alnemri, Kimmel Cancer Institute, Thomas Jefferson University for providing us with the images in Figure 2. This work was supported by grants from the Canadian Institute for Health Research and the Canada Foundation for Innovation. MS is a Canadian Institute for Health Research New Investigator.

1. Weinrauch Y, Zychlinsky A. The induction of apoptosis by bacterial pathogens. Annu Rev Microbiol 1999; 53: 155-187.

2. Hay S, Kannourakis G. A time to kill: viral manipulation of the cell death program. J Gen Virol 2002; 83: 1547-1564.

3. James ER, Green DR. Manipulation of apoptosis in the host-parasite interaction Trends Parasitol 2004; 20: 280-287.
4. Clemens DL. Characterization of the Mycobacterium tuberculosis phagosome. Trends Microbiol 1996; 4: 113-118.

5. Fairbairn IP. Macrophage apoptosis in host immunity to mycobacterial infections. Biochem Soc Trans 2004; 32: 496-498.

6. Grassme H, Jendrossek V, Gulbins E. Molecular mechanisms of bacteria-induced apoptosis. Apoptosis 2001; 6: 441-445.

7. Savill J, Fadok V. Corpse clearance defines the meaning of cell death. Nature 2000; 407 : 784-788.

8. Yrlid U, Wick MJ. Salmonella-induced apoptosis of infected macrophages results in presentation of a bacteria-encoded antigen after uptake by bystander dendritic cells. $J$ Exp Med 2000; 191: 613-624.

9. Schaible UE, Winau F, Sieling PA, Fischer K, Collins HL, Hagens K et al. Apoptosis facilitates antigen presentation to T lymphocytes through MHC-I and CD1 in tuberculosis. Nat Med 2003; 9: 1039-1046.

10. Albert ML. Death-defying immunity: do apoptotic cells influence antigen processing and presentation? Nat Rev Immunol 2004; 4: 223-231.

11. Dockrell DH. Apoptotic cell death in the pathogenesis of infectious diseases. J Infect 2001; 42: 227-234.

12. Clifton DR, Goss RA, Sahni SK, van Antwerp D, Baggs RB, Marder VJ et al. NF-kappa Bdependent inhibition of apoptosis is essential for host cellsurvival during Rickettsia rickettsii infection. Proc Natl Acad Sci USA 1998; 95: 4646-4651.

13. Fan T, Lu H, Hu H, Shi L, McClarty GA, Nance DM et al. Inhibition of apoptosis in chlamydia-infected cells: blockade of mitochondrial cytochrome $c$ release and caspase activation. J Exp Med 1998; 187: 487-496.

14. Hanna PC, Acosta D, Collier RJ. On the role of macrophages in anthrax. Proc Natl Acad Sci USA 1993; 90: 10198-10201.

15. Taichman NS, Dean RT, Sanderson CJ. Biochemical and morphological characterization of the killing of human monocytes by a leukotoxin derived from Actinobacillus actinomycetemcomitans. Infect Immun 1980; 28: 258-268.

16. Kato S, Muro M, Akifusa S, Hanada N, Semba I, Fujii T et al. Evidence for apoptosis of murine macrophages by Actinobacillus actinomycetemcomitans infection. Infect Immun 1995; 63: 3914-3919.

17. Kochi SK, Collier RJ. DNA fragmentation and cytolysis in U937 cells treated with diphtheria toxin or other inhibitors of protein synthesis. Exp Cell Res 1993; 208: 296-302.

18. Morimoto $\mathrm{H}$, Bonavida $B$. Diphtheria toxin- and Pseudomonas A toxin-mediated apoptosis. ADP ribosylation of elongation factor-2 is required for DNA fragmentation and cell lysis and synergy with tumor necrosis factor-alpha. J Immunol 1992; 149: 2089-2094

19. Khelef N, Zychlinsky A, Guiso N. Bordetella pertussis induces apoptosis in macrophages: role of adenylate cyclase-hemolysin. Infect Immun 1993; 61: 4064-4071.

20. Boatright KM, Renatus M, Scott FL, Sperandio S, Shin H, Pedersen IM et al. A unified model for apical caspase activation. Mol Cell 2003; 11: 529-541.

21. Ekert PG, Vaux DL. The mitochondrial death squad: hardened killers or innocent bystanders? Curr Opin Cell Biol 2005; 17: 626-630.

22. Green DR, Kroemer G. The pathophysiology of mitochondrial cell death. Science 2004; 305: 626-629.

23. Riedl SJ, Salvesen GS. The apoptosome: signalling platform of cell death. Nat Rev Mol Cell Biol 2007; 8: 405-413.

24. Peter ME, Krammer PH. The CD95(APO-1/Fas) DISC and beyond. Cell Death Differ 2003; 10: 26-35.

25. Taylor RC, Cullen SP, Martin SJ. Apoptosis: controlled demolition at the cellular level. Nat Rev Mol Cell Biol 2008; 9: 231-241.

26. Collier-Hyams LS, Zeng H, Sun J, Tomlinson AD, Bao ZQ, Chen $\mathrm{H}$ et al. Cutting edge: salmonella AvrA effector inhibits the key proinflammatory, anti-apoptotic NF-kappa B pathway. J Immunol 2002; 169: 2846-2850.

27. Orth K, Palmer LE, Bao ZQ, Stewart S, Rudolph AE, Bliska JB et al. Inhibition of the mitogen-activated protein kinase kinase superfamily by a Yersinia effector. Science 1999; 285: $1920-1923$.

28. Schesser K, Spiik AK, Dukuzumuremyi JM, Neurath MF, Pettersson S, Wolf-Watz H. The yopJ locus is required for Yersinia-mediated inhibition of NF-kappaB activation and cytokine expression: YopJ contains a eukaryotic SH2-like domain that is essential for its repressive activity. Mol Microbiol 1998; 28: 1067-1079.

29. Park JM, Greten FR, Li ZW, Karin M. Macrophage apoptosis by anthrax lethal factor through P38 MAP kinase inhibition. Science 2002; 297: 2048-2051.

30. Marriott HM, Bingle CD, Read RC, Braley KE, Kroemer G, Hellewell PG et al. Dynamic changes in Mcl-1 expression regulate macrophage viability or commitment to apoptosis during bacterial clearance. J Clin Invest 2005; 115: 359-368.

31. Grassme H, Kirschnek S, Riethmueller J, Riehle A, von Kurthy G, Lang F et al. CD95/ CD95 ligand interactions on epithelial cells in host defense to Pseudomonas aeruginosa. Science 2000; 290: 527-530.

32. Jones NL, Day AS, Jennings H, Shannon PT, Galindo-Mata E, Sherman PM. Enhanced disease severity in Helicobacter pylori-infected mice deficient in Fas signaling. Infect Immun 2002; 70: 2591-2597.

33. Cai X, Stoicov C, Li H, Carlson J, Whary M, Fox JG et al. Overcoming Fas-mediated apoptosis accelerates Helicobacter-induced gastric cancer in mice. Cancer Res 2005; 65: 10912-10920. 
34. Kanaly ST, Nashleanas M, Hondowicz B, Scott $P$. TNF receptor p55 is required for elimination of inflammatory cells following control of intracellular pathogens. J Immunol 1999; 163: 3883-3889.

35. Haslett C. Granulocyte apoptosis and its role in the resolution and control of lung inflammation. Am J Respir Crit Care Med 1999; 160: S5-11.

36. Hotchkiss RS, Nicholson DW. Apoptosis and caspases regulate death and inflammation in sepsis. Nat Rev Immunol 2006; 6: 813-822.

37. Hotchkiss RS, Chang KC, Swanson PE, Tinsley KW, Hui JJ, Klender P et al. Caspase inhibitors improve survival in sepsis: a critical role of the lymphocyte. Nat Immunol 2000; 1: $496-501$.

38. Hotchkiss RS, Swanson PE, Knudson CM, Chang KC, Cobb JP, Osborne DF et al. Overexpression of $\mathrm{Bcl}-2$ in transgenic mice decreases apoptosis and improves survival in sepsis. J Immunol 1999; 162: 4148-4156.

39. Mathan MM, Mathan VI. Morphology of rectal mucosa of patients with shigellosis Rev Infect Dis 1991; 13 (Suppl 4): S314-S318.

40. Menard R, Sansonetti PJ, Parsot C. Nonpolar mutagenesis of the ipa genes defines IpaB, IpaC, and IpaD as effectors of Shigella flexneri entry into epithelial cells. J Bacteriol 1993; 175: 5899-5906.

41. Zychlinsky A, Prevost MC, Sansonetti PJ. Shigella flexneri induces apoptosis in infected macrophages. Nature 1992; 358: 167-169.

42. Chen $Y$, Smith MR, Thirumalai $K$, Zychlinsky A. A bacterial invasin induces macrophage apoptosis by binding directly to ICE. EMBO J 1996; 15: 3853-3860.

43. Hilbi H, Moss JE, Hersh D, Chen Y, Arondel J, Banerjee $S$ et al. Shigella-induced apoptosis is dependent on caspase-1 which binds to IpaB. J Biol Chem 1998; 273 32895-32900.

44. Hersh D, Monack DM, Smith MR, Ghori N, Falkow S, Zychlinsky A. The Salmonella invasin $\mathrm{SipB}$ induces macrophage apoptosis by binding to caspase-1. Proc Natl Acad Sci USA 1999; 96: 2396-2401.

45. Brennan MA, Cookson BT. Salmonella induces macrophage death by caspase-1dependent necrosis. Mol Microbiol 2000; 38: 31-40.

46. Lara-Tejero M, Sutterwala FS, Ogura Y, Grant EP, Bertin J, Coyle AJ et al. Role of the caspase-1 inflammasome in Salmonella typhimurium pathogenesis. $J$ Exp Med 2006 203: 1407-1412.

47. Mariathasan S, Newton K, Monack DM, Vucic D, French DM, Lee WP et al. Differentia activation of the inflammasome by caspase-1 adaptors ASC and Ipaf. Nature 2004; 430: 213-218.

48. Jesenberger V, Procyk KJ, Yuan J, Reipert S, Baccarini M. Salmonella-induced caspase2 activation in macrophages: a novel mechanism in pathogen-mediated apoptosis. $J$ Exp Med 2000; 192: 1035-1046.

49. van der Velden AW, Velasquez M, Starnbach MN. Salmonella rapidly kill dendritic cells via a caspase-1-dependent mechanism. J Immunol 2003; 171: 6742-6749.

50. Cervantes J, Nagata T, Uchijima M, Shibata K, Koide Y. Intracytosolic Listeria monocytogenes induces cell death through caspase- 1 activation in murine macrophages. Cell Microbiol 2008; 10: 41-52.

51. Sutterwala FS, Mijares LA, Li L, Ogura Y, Kazmierczak BI, Flavell RA. Immune recognition of Pseudomonas aeruginosa mediated by the IPAF/NLRC4 inflammasome. J Exp Med 2007; 204: 3235-3245.

52. Mariathasan S, Weiss DS, Dixit VM, Monack DM. Innate immunity against Francisella tularensis is dependent on the ASC/caspase-1 axis. J Exp Med 2005; 202 1043-1049.

53. Zamboni DS, Kobayashi KS, Kohlsdorf T, Ogura Y, Long EM, Vance RE et al. The Birc1e cytosolic pattern-recognition receptor contributes to the detection and control of Legionella pneumophila infection. Nat Immunol 2006; 7: 318-325.

54. Molofsky AB, Byrne BG, Whitfield NN, Madigan CA, Fuse ET, Tateda K et al. Cytosolic recognition of flagellin by mouse macrophages restricts Legionella pneumophila infection. J Exp Med 2006; 203: 1093-1104

55. Bergsbaken T, Cookson BT. Macrophage activation redirects yersinia-infected host cell death from apoptosis to caspase-1-dependent pyroptosis. PLOS Pathog 2007; 3: e161.

56. Sun GW, Lu J, Pervaiz S, Cao WP, Gan YH. Caspase-1 dependent macrophage death induced by Burkholderia pseudomallei. Cell Microbiol 2005; 7: 1447-1458.

57. Thornberry NA, Bull HG, Calaycay JR, Chapman KT, Howard AD, Kostura MJ et al. A novel heterodimeric cysteine protease is required for interleukin-1 beta processing in monocytes. Nature 1992; 356: 768-774.

58. Dinarello CA. An IL-1 family member requires caspase-1 processing and signals through the ST2 receptor. Immunity 2005; 23: 461-462.

59. Fantuzzi G, Dinarello CA. Interleukin-18 and interleukin-1 beta: two cytokine substrates for ICE (caspase-1). J Clin Immunol 1999; 19: 1-11.

60. Kuida K, Lippke JA, Ku G, Harding MW, Livingston DJ, Su MS et al. Altered cytokine export and apoptosis in mice deficient in interleukin-1 beta converting enzyme. Science 1995; 267: 2000-2003.

61. Li P, Allen H, Banerjee S, Franklin S, Herzog L, Johnston C et al. Mice deficient in IL-1 beta-converting enzyme are defective in production of mature IL-1 beta and resistant to endotoxic shock. Cell 1995; 80: 401-411.

62. Ghayur T, Banerjee S, Hugunin M, Butler D, Herzog L, Carter A et al. Caspase-1 processes IFN-gamma-inducing factor and regulates LPS-induced IFN-gamma production. Nature 1997; 386: 619-623
63. Monack DM, Navarre WW, Falkow S. Salmonella-induced macrophage death: the role of caspase-1 in death and inflammation. Microbes Infect 2001; 3: 1201-1212.

64. Cookson BT, Brennan MA. Pro-inflammatory programmed cell death. Trends Microbio 2001; 9: 113-114.

65. Fink SL, Cookson BT. Caspase-1-dependent pore formation during pyroptosis leads to osmotic lysis of infected host macrophages. Cell Microbiol 2006; 8: 1812-1825.

66. Monack DM, Raupach B, Hromockyj AE, Falkow S. Salmonella typhimurium invasion induces apoptosis in infected macrophages. Proc Natl Acad Sci USA 1996; 93 9833-9838.

67. Hilbi H, Chen Y, Thirumalai K, Zychlinsky A. The interleukin 1beta-converting enzyme, caspase 1, is activated during Shigella flexneri-induced apoptosis in human monocytederived macrophages. Infect Immun 1997; 65: 5165-5170.

68. Fernandes-Alnemri T, Wu J, Yu J, Datta P, Miller B, Jankowski W et al. The pyroptosome: a supramolecular assembly of ASC dimers mediating inflammatory cell death via caspase-1 activation. Cell Death and Differ 2007; 14: 1590-1604.

69. Fink SL, Cookson BT. Pyroptosis and host cell death responses during Salmonella infection. Cell Microbiol 2007; 9: 2562-2570.

70. Shao W, Yeretssian G, Doiron K, Hussain SN, Saleh M. The caspase-1 digestome identifies the glycolysis pathway as a target during infection and septic shock. J Biol Chem 2007; 282: 36321-36329.

71. Keller M, Ruegg A, Werner S, Beer HD. Active caspase- 1 is a regulator of unconventiona protein secretion. Cell 2008; 132: 818-831.

72. Kovacsovics M, Martinon F, Micheau O, Bodmer JL, Hofmann K, Tschopp J Overexpression of Helicard, a CARD-containing helicase cleaved during apoptosis, accelerates DNA degradation. Curr Biol 2002; 12: 838-843.

73. Philpott DJ, Girardin SE. The role of Toll-like receptors and Nod proteins in bacterial infection. Mol Immunol 2004; 41: 1099-1108.

74. Nadiri A, Wolinski MK, Saleh M. The inflammatory caspases: key players in the host response to pathogenic invasion and sepsis. J Immunol 2006; 177: 4239-4245.

75. Agostini L, Martinon F, Burns K, McDermott MF, Hawkins PN, Tschopp J. NALP3 forms an IL-1beta-processing inflammasome with increased activity in Muckle-Wells autoinflammatory disorder. Immunity 2004; 20: 319-325.

76. Martinon F, Agostini L, Meylan E, Tschopp J. Identification of bacterial muramyl dipeptide as activator of the NALP3/cryopyrin inflammasome. Curr Biol 2004; 14 1929-1934.

77. Poyet JL, Srinivasula SM, Tnani M, Razmara M, Fernandes-Alnemri T, Alnemri ES. Identification of Ipaf, a human caspase-1-activating protein related to Apaf-1. J Biol Chem 2001; 276: 28309-28313.

78. Martinon F, Burns K, Tschopp J. The inflammasome: a molecular platform triggering activation of inflammatory caspases and processing of prolL-beta. Mol Cell 2002; 10 $417-426$

79. Faustin B, Lartigue L, Bruey JM, Luciano F, Sergienko E, Bailly-Maitre B et al Reconstituted NALP1 inflammasome reveals two-step mechanism of caspaseactivation. Mol Cell 2007; 25: 713-724.

80. Mariathasan S, Monack DM. Inflammasome adaptors and sensors: intracellular regulators of infection and inflammation. Nat Rev Immunol 2007; 7: 31-40.

81. Mariathasan S, Weiss DS, Newton K, McBride J, O'Rourke K, Roose-Girma M et al. Cryopyrin activates the inflammasome in response to toxins and ATP. Nature 2006; 440 228-232.

82. Franchi L, Amer A, Body-Malapel M, Kanneganti TD, Ozoren N, Jagirdar R et al. Cytosolic flagellin requires Ipaf for activation of caspase-1 and interleukin 1beta in salmonellainfected macrophages. Nat Immunol 2006; 7: 576-582.

83. Miao EA, Alpuche-Aranda CM, Dors M, Clark AE, Bader MW, Miller SI et al. Cytoplasmic flagellin activates caspase-1 and secretion of interleukin 1beta via Ipaf. Nat Immunol 2006; 7: 569-575.

84. Sutterwala FS, Ogura Y, Szczepanik M, Lara-Tejero M, Lichtenberger GS, Grant EP et al. Critical role for NALP3/CIAS1/Cryopyrin in innate and adaptive immunity through its regulation of caspase-1. Immunity 2006; 24: 317-327.

85. Boyden ED, Dietrich WF. Nalp1b controls mouse macrophage susceptibility to anthrax lethal toxin. Nat Genet 2006; 38: 240-244.

86. Franchi L, Stoolman J, Kanneganti TD, Verma A, Ramphal R, Nunez G. Critical role for Ipaf in Pseudomonas aeruginosa-induced caspase-1 activation. Eur J Immunol 2007; 37 : 3030-3039.

87. Cornelis GR. The type III secretion injectisome. Nat Rev Microbiol 2006; 4: 811-825.

88. Portnoy DA, Auerbuch V, Glomski IJ. The cell biology of Listeria monocytogenes infection: the intersection of bacterial pathogenesis and cell-mediated immunity. J Cell Biol 2002; 158: 409-414.

89. Amer A, Franchi L, Kanneganti TD, Body-Malapel M, Ozoren N, Brady G et al. Regulation of Legionella phagosome maturation and infection through flagellin and host Ipaf. $J$ Biol Chem 2006; 281: 35217-35223.

90. Suzuki T, Franchi L, Toma C, Ashida H, Ogawa M, Yoshikawa $Y$ et al. Differential regulation of caspase-1 activation, pyroptosis, and autophagy via Ipaf and ASC in Shigella-infected macrophages. PLoS Pathog 2007; 3: e111.

91. Miao EA, Ernst RK, Dors M, Mao DP, Aderem A. Pseudomonas aeruginosa activates caspase 1 through Ipaf. Proc Natl Acad Sci USA 2008; 105: 2562-2567.

92. Lamkanfi M, Kanneganti TD, Franchi L, Nunez G. Caspase-1 inflammasomes in infection and inflammation. J Leukoc Biol 2007; 82: 220-225. 
93. Druilhe A, Srinivasula SM, Razmara M, Ahmad M, Alnemri ES. Regulation of IL-1beta generation by Pseudo-ICE and ICEBERG, two dominant negative caspase recruitment domain proteins. Cell Death Differ 2001; 8: 649-657.

94. Yu JW, Wu J, Zhang Z, Datta P, Ibrahimi I, Taniguchi S et al. Cryopyrin and pyrin activate caspase-1, but not NF-kappaB, via ASC oligomerization. Cell Death Differ 2006; 13: 236-249.

95. Chae JJ, Komarow HD, Cheng J, Wood G, Raben N, Liu PP et al. Targeted disruption of pyrin, the FMF protein, causes heightened sensitivity to endotoxin and a defect in macrophage apoptosis. Mol Cell 2003; 11: 591-604.

96. Saleh MM, Mathison JC, Wolinski MK, Bensinger SJ, Fitzgerald P, Droin N et al. Enhanced bacterial clearance and sepsis resistance in caspase-12 deficient mice. Nature 2006; 440: 1064-1068.

97. Dinarello CA. Biologic basis for interleukin-1 in disease. Blood 1996; 87: 2095-2147.

98. Fantuzzi G, Zheng H, Faggioni R, Benigni F, Ghezzi P, Sipe JD et al. Effect of endotoxin in IL-1 beta-deficient mice. J Immunol 1996; 157: 291-296.

99. Sarkar A, Hall MW, Exline M, Hart J, Knatz N, Gatson NT et al. Caspase-1 regulates Escherichia coli sepsis and splenic B cell apoptosis independently of interleukin-1beta and interleukin-18. Am J Respir Crit Care Med 2006; 174: 1003-1010.

100. Majno G, Joris I. Apoptosis, oncosis, and necrosis. An overview of cell death. Am J Pathol 1995; 146: 3-15.

101. Festiens N, Vanden Berghe T, Vandenabeele P. Necrosis, a well-orchestrated form of cell demise: signalling cascades, important mediators and concomitant immune response. Biochim Biophys Acta 2006; 1757: 1371-1387.

102. O'Sullivan MP, O'Leary S, Kelly DM, Keane J. A caspase-independent pathway mediates macrophage cell death in response to Mycobacterium tuberculosis infection. Infect Immun 2007; 75: 1984-1993.

103. Lee J, Remold HG, leong MH, Kornfeld H. Macrophage apoptosis in response to high intracellular burden of Mycobacterium tuberculosis is mediated by a novel caspaseindependent pathway. J Immunol 2006; 176: 4267-4274.
104. Willingham SB, Bergstralh DT, O'Connor W, Morrison AC, Taxman DJ, Duncan JA et al. Microbial pathogen-induced necrotic cell death mediated by the inflammasome components CIAS1/cryopyrin/NLRP3 and ASC. Cell Host Microbe 2007; 2: 147-159.

105. Levine B, Yuan J. Autophagy in cell death: an innocent convict? J Clin Invest 2005; 115: 2679-2688.

106. Levine B, Deretic V. Unveiling the roles of autophagy in innate and adaptive immunity. Nat Rev Immunol 2007; 7: 767-777.

107. Gutierrez MG, Master SS, Singh SB, Taylor GA, Colombo MI, Deretic V. Autophagy is a defense mechanism inhibiting BCG and Mycobacterium tuberculosis survival in infected macrophages. Cell 2004; 119: 753-766.

108. Nakagawa I, Amano A, Mizushima N, Yamamoto A, Yamaguchi H, Kamimoto $\mathrm{T}$ et al. Autophagy defends cells against invading group A Streptococcus. Science 2004; 306 : 1037-1040.

109. Py BF, Lipinski MM, Yuan J. Autophagy limits Listeria monocytogenes intracellular growth in the early phase of primary infection. Autophagy 2007; 3: 117-125

110. Birmingham CL, Smith AC, Bakowski MA, Yoshimori T, Brumell JH. Autophagy controls Salmonella infection in response to damage to the Salmonella-containing vacuole. J Biol Chem 2006; 281: 11374-11383.

111. Checroun C, Wehrly TD, Fischer ER, Hayes SF, Celli J. Autophagy-mediated reentry of Francisella tularensis into the endocytic compartment after cytoplasmic replication. Proc Natl Acad Sci USA 2006; 103: 14578-14583.

112. Jackson WT, Giddings Jr TH, Taylor MP, Mulinyawe S, Rabinovitch M, Kopito RR et al. Subversion of cellular autophagosomal machinery by RNA viruses. PLOS Biol 2005; 3: e156.

113. Kirkegaard K, Taylor MP, Jackson WT. Cellular autophagy: surrender, avoidance and subversion by microorganisms. Nat Rev Microbiol 2004; 2 : 301-314

114. Munz C. Autophagy and antigen presentation. Cell Microbiol 2006; 8: 891-898. 